\title{
Isolated CNS Whipple's disease: a diagnostic dilemma
}

\author{
Amartya Kundu, ${ }^{1}$ Parijat Sen, ${ }^{2}$ Sharad Khurana ${ }^{3}$
}

${ }^{1}$ Department of Internal Medicine, University of Massachusetts Medical School, Worcester, Massachusetts, USA ${ }^{2}$ Department of Internal Medicine/Medical Education, Saint Michael's Medical Center, Newark, New Jersey, USA

${ }^{3}$ Department of Internal Medicine, John H Stroger Jr Hospital of Cook County, Chicago, Illinois, USA

\section{Correspondence to} Dr Parijat Sen,

parijatsenstation@gmail.com

Accepted 3 August 2015

\section{DESCRIPTION}

A 64-year-old diabetic Caucasian man presented with progressively worsening neurological symptoms including memory loss, involuntary teeth clenching, difficulty maintaining balance, daytime somnolence and cognitive impairment for the past 2 years. Nine months prior, CT scan of the brain had shown mild uncomplicated hydrocephalus (figure 1).

The patient underwent further evaluation with a brain MRI, which demonstrated an apparent web traversing the cerebral aqueduct at its midpoint with faint associated enhancement (figure 2). The lateral and third ventricles were noted to be enlarged but unchanged compared to prior CT. The extra-axial cerebrospinal fluid (CSF) spaces were of normal size. There were periventricular hyperintensities suggestive of chronic small vessel ischaemia and/or transependymal fluid shift.

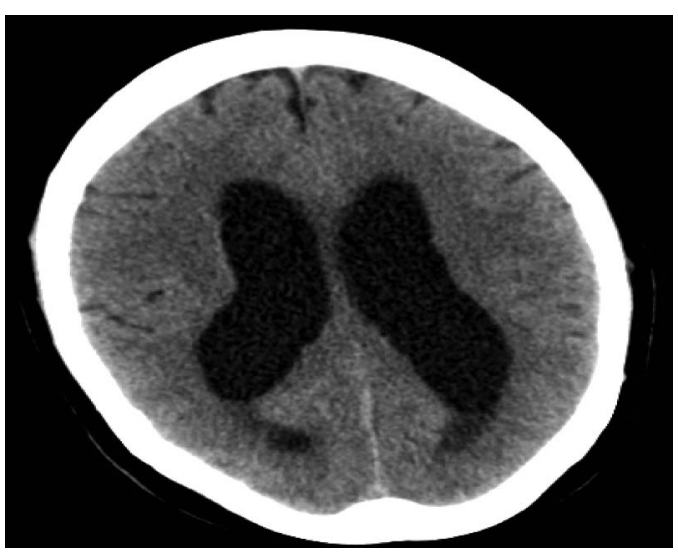

Figure 1 CT scan showing dilated lateral ventricles.

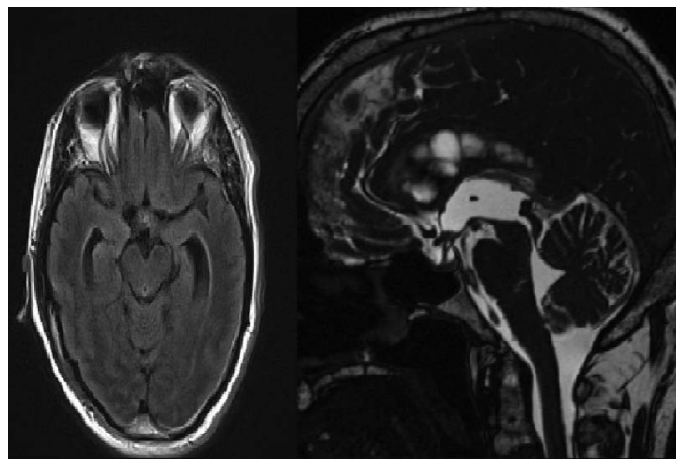

Khurana S. BMJ Case Rep Published online: [please include Day Month Year] doi:10.1136/bcr-2015211784

CrossMark
Figure 2 MRI showing an apparent web traversing the cerebral aqueduct at its midpoint along with periventricular hyperintensities.
CISS images showed a small web traversing the cerebral aqueduct at its midpoint with distention of the proximal half of the aqueduct in comparison to the distal half. Lumbar puncture was then performed and showed a normal CSF analysis,

\section{Learning points}

- Whipple's disease, a systemic infectious disease caused by the bacterium Tropheryma whipplei, primarily causes malabsorption but may affect any part of the body including the heart, lungs, brain, joints, skin and the eyes. Isolated involvement of the central nervous system (CNS) with Whipple's disease is rare, but has been reported in the medical literature. ${ }^{2}$ The rarity of this disease may not be only related to low incidence of the disease itself, but may also be due to diagnostic challenges. ${ }^{3}$ As exemplified in our report, the condition requires a high index of suspicion to diagnose. There are many countries where such infections are more common but these regions may lack the facilities to conduct the elaborate investigations required for diagnosis.

- Neurological presentation can be atypical with a wide spectrum of signs and symptoms, and various associated imaging abnormalities. The most frequent neurological signs are cognitive and behavioural changes, supranuclear gaze palsy and altered level of consciousness. Oculomasticatory myorhythmia and oculofacial-skeletal myorhythmia are thought to be pathognomonic for CNS Whipple's disease. ${ }^{1}$ Other neurological symptoms such as rhythmic myoclonus, dementia, psychiatric symptoms and hypothalamic manifestations may be present, while systemic signs may include fever of unknown origin, gastrointestinal symptoms, arthralgia, lymphadenopathy and night sweats. ${ }^{1}$

- The disease can be fatal in the setting of an inaccurate diagnosis without institution of appropriate antibiotics. It warrants close follow-up after discharge from the hospital as a number of patients reportedly relapse with progressive neurological involvement after initial successful treatment. ${ }^{3}$ The rate of relapse is particularly high with tetracycline (up to $35 \%$ ) and one of the cases of chronically relapsing CNS Whipple's was successfully treated with recombinant $\gamma$ interferon along with conventional antibiotics. ${ }^{4}$ 
negative CSF herpes simplex virus PCR, oligoclonal bands and vasculitis markers.

It was decided to test the patient for possible Whipple's disease (despite lack of known exposure) based on the negative clinical work up thus far and extensive MRI abnormalities, with concern that his intermittent jaw clenching could be an atypical presentation of oculomasticatory myorhythmia-a unique movement disorder seen in Whipple's disease. ${ }^{1}$ CSF PCR for Tropheryma whipplei returned positive, thereby confirming diagnosis of central nervous system Whipple's. The patient was eventually discharged on 4 weeks of intravenous ceftriaxone followed by trimethoprim-sulfamethoxazole for 1 year, with follow-up scheduled in 3 months.
Competing interests None declared.

\section{Patient consent Obtained.}

Provenance and peer review Not commissioned; externally peer reviewed.

\section{REFERENCES}

1 Louis ED, Lynch T, Kaufmann P, et al. Diagnostic guidelines in central nervous system Whipple's disease. Ann Neurol 1996;40:561-8.

2 Adams M, Rhyner PA, Day J, et al. Whipple's disease confined to the central nervous system. Ann Neurol 1987;21:104-8.

3 von Herbay A, Ditton HJ, Schuhmacher F, et al. Whipple's disease: staging and monitoring by cytology and polymerase chain reaction analysis of cerebrospinal fluid. Gastroenterology 1997;113:434-41.

4 Schneider T, Stallmach A, von Herbay A, et al. Treatment of refractory Whipple disease with interferon-gamma. Ann Intern Med 1998;129:875-7.

Copyright 2015 BMJ Publishing Group. All rights reserved. For permission to reuse any of this content visit

http://group.bmj.com/group/rights-licensing/permissions.

BMJ Case Report Fellows may re-use this article for personal use and teaching without any further permission.

Become a Fellow of BMJ Case Reports today and you can:

- Submit as many cases as you like

- Enjoy fast sympathetic peer review and rapid publication of accepted articles

- Access all the published articles

- Re-use any of the published material for personal use and teaching without further permission

For information on Institutional Fellowships contact consortiasales@bmjgroup.com

Visit casereports.bmj.com for more articles like this and to become a Fellow 